\title{
Reconceptualising ecological fiscal transfers to sustainable development perspective
}

\section{Felipe Luiz Lima de Paulo*}

Universidade Federal Rural de Pernambuco,

Avenida Gregório Ferraz Nogueira José Tomé de Souza Ramos, 56909535 - Serra Talhada, Pernambuco, Brazil

Email: felipe.paulo@ufrpe.br

${ }^{*}$ Corresponding author

\section{Ivo Vasconcelos Pedrosa}

Universidade de Pernambuco - UPE,

Núcleo de Pesquisas em Economia do Setor Público - NUPESP, Rua Casa Forte, 65, apto. 1101, bairro Casa Forte, Recife, Pernambuco, Brazil

Email: ivo@nupesp.org

\section{Pedro Jorge Sobral Camões}

Universidade do Minho,

Escola de Economia e Gestão,

Campus de Gualtar, 4710-057, Braga, Portugal

Email: pedroc@eeg.uminho.pt

\begin{abstract}
Ecological fiscal transfers (EFTs) is a policy schema that uses ecological indicators to allocate revenues to local governments. Such intergovernmental fiscal transfers are also suited to address social policies, such as the protection of indigenous land and the reduction of infant and child mortality rates. This study offers a new conceptualisation of EFT to achieve sustainable local development that brings together economic, ecological, and social perspectives. Framed on the theories of environmental federalism, fiscal federalism, and public policy, this paper unfolds the concept of sustainable fiscal transfers (SFTs) rather than the more conventional EFTs. SFTs expand the potential of the EFT to other policies, functioning as a policy tool to reach goals in social, economic and environmental policies at the local level. In order to illustrate this new conceptualisation, it describes the SFTs as a Brazilian state policy.
\end{abstract}

Keywords: EFTs; ecological fiscal transfers; SFTs; sustainable fiscal transfers; sustainable development; fiscal federalism; Brazil; local governments; state governments; ICMS.

Reference to this paper should be made as follows: de Paulo, F.L.L., Pedrosa, I.V. and Camões, P.J.S. (2022) 'Reconceptualising ecological fiscal transfers to sustainable development perspective', Int. J. Innovation and Sustainable Development, Vol. 16, No. 1, pp.22-31. 
Biographical notes: Felipe Luiz Lima de Paulo is an Assistant Professor at the Universidade Federal Rural de Pernambuco and researcher in the NUPESP (Research Group in Economics of the Public Sector) at the Universidade de Pernambuco, Brazil. He holds a PhD in Administrative Sciences from the University of Minho, Portugal. His research focuses on issues related to environmental policies and public finance.

Ivo Vasconcelos Pedrosa is a retired full professor of Economics at the Universidade de Pernambuco, Brazil, and the leader of the NUPESP (Research Group in Economics of the Public Sector) at the University of Pernambuco, Brazil. He holds a $\mathrm{PhD}$ in Economics from the Universidade Estadual de Campinas, Brazil. His research focuses on issues related to environmental policies, local government, ICMS, tax reform, value-added tax, and fiscal federalism.

Pedro Jorge Sobral Camões holds a PhD in Political Science (Major in Public Administration) from the University of South Carolina with research interests on public service delivery and public finance. He is an Assistant Professor of the School of Economics and Management and member of the Research Center in Political Science at the University of Minho, Portugal.

This paper is a revised and expanded version of a paper entitled 'Interactions between fiscal federalism and the environment: the case of the sustainable fiscal transfers in the State of Pernambuco, Brazil (2011-2015)' presented at the 24th World Congress of Political Science of the International Political Science Association, Poznan, 23-28 July, 2016.

\section{Introduction}

The literature presents two main policy tools to protect the biodiversity at the local level: payment for environmental services (PES) (Salzman, 2005); and ecological fiscal transfers (EFTs) (Ring and Barton, 2015). PES is suitable to incentivise the users of private resources in their effort to protect the environment, while EFTs aim to incentivise local governments to create protected areas (PAs). EFTs are also designed to compensate local governments for hosting PAs imposed by upper levels of government. The rationale is the idea that the decentralisation of environmental policies is the most efficient institutional arrangement. Local authorities are able to minimise information costs of knowing citizens' preferences regarding the level of environmental quality.

EFTs developed worldwide as a relatively novel policy tool; it has solely been adopted in Brazil (Loureiro, 2002; Ring, 2008; Moura, 2015), Portugal (Droste et al., 2017a; Santos et al., 2012), and France (Borie et al., 2014). An extensive literature focuses on the role of EFTs to secure the conservation of biodiversity at the local level. In Brazil, the fiscal transfers from the states to municipalities adopt a Value Added Tax called ICMS. It adopts the 'principle of the protector-receiver' which implies more money transferred from ICMS to local governments that protect the environment (Jatobá, 2005).

The first Brazilian state to adopt EFT was Paraná (Ring, 2008). Other states followed the diffusion process and adopted similar fiscal transfers (de Medeiros, 2013). In the specific case of the state of Pernambuco, the maintenance of EFTs is justified by the 
importance of stimulating environmental policies at the local sphere. ${ }^{1}$ With this regard, Pedrosa (2013) describes a downward trend in the anthropogenic pressure from urban areas to the countryside, particularly in the case of protected areas and solid waste treatment and disposal (de Paulo 2013). In addition, the most populous municipalities of urban areas hold more resources for environmental management, that is, they are in a better position to deal more adequately with environmental policies in their territories (Pedrosa, 2013). EFTs may also contribute to the redistribution of money among municipalities and mitigate the imbalances between urban and countryside areas to protect the environment.

Sometimes EFTs also include environmental and social policies less frequently addressed in the literature, such as solid waste management (SWM), water conservation, fire-control, and indigenous land protection. For instance, nine states use SWM policies Mato Grosso, Ceará, Rio de Janeiro, Mato Grosso do Sul, Minas Gerais, Pernambuco, Tocantins, Piauí, Goiás - which stimulates local governments to foster these policies in their territories. In the end, each state is free to design and implement EFT according to its specific needs, institutional capacity, as well as political circumstances (de Paulo, 2019).

Given its ability to reach various social and environmental policies, EFTs have the potential to achieve sustainable development at the local sphere. The Brundtland Commission defines sustainable development as a "development that meets the needs of the present without compromising the ability of future generations to meet their own needs" (World Commission on Environment and Development (WCED), 1987, p.41). However, a conceptualisation of EFTs to include sustainable development has never been explored so far. This essay aims to answer the following question: how do EFT contribute to improve sustainable development at the local level? It adopts sustainable fiscal transfers (SFTs) and offers a descriptive case study based on SFTs adopted in the State of Pernambuco (law 11.899/2000) during the period from 2002 to 2018.

The essay is structured in five sections. The next section provides a literature review of SFTs in Brazil and other countries based on the public finance theory, and section three conceptualises SFTs. The research design and the explanation of the evolving process of the design of SFTs in the State of Pernambuco are presented in sections four and five. The conclusion discusses directions for future research.

\section{Literature review}

The decentralisation of environmental policies at the local level has at least three benefits (Oates, 2001). First, local governments incur in lower costs to extract accurate information out of citizens' preference with regard to environmental quality, while central governments find it more costly. Second, the decentralisation of environmental policies is prone to increase citizens' participation in local decisions and to provide an appropriate consumption of environmental public goods. Third, it increases the ability of local governments to guarantee a certain level of biodiversity by reducing impacts on ecosystems for future generations.

The allocation of financial resources for environmental policies to local governments contributes to sustainable development. It allows poverty reduction and increases the current and future welfare for populations. In less-developed countries characterised by 
several regional inequalities, this is more prominent because poor regions are typically marginalised in the policy process and in their ability to avoid externalities (Steer and Wade-Gery, 1993).

Coordination to introduce environmental policies is necessary to avoid such inefficiencies. If adopted by a single municipality, certain types of environmental policies may impose benefits or losses to other jurisdictions, which induce free-riding behaviour to appear. For example, PA adopted by a single local government may provide clean air or clean water to other municipalities. Another example is when municipalities adopt an irregular garbage dump that pollutes other jurisdictions.

Among other policy tools, an upper level of government may use EFT to impose coordination of environmental policies to a lower level of government. EFT allocates money from higher to lower level governments based on ecological indicators (Ring and Barton, 2015, p.438).

EFTs have two main characteristics. First, they serve as an incentive for local governments to internalise the spillover effects. Second, they are a means of financial compensation for producing environmental public goods beyond the local government's borders. Sauquet et al. (2014, p.250) note their critical relevance in the creation of protected areas that ultimately foster biodiversity and reward local governments for hosting protected areas imposed by the state governments. The ways EFTs function in reducing biodiversity loss are analogous to the mechanisms underlying collective action (Olson, 1965) and the theory of fiscal equivalence (Olson, 1969).

EFTs have been adopted in two countries so far, Brazil and Portugal (Ring, 2008, Santos et al., 2012), although they have also been introduced to a lesser extent in France (Borie et al., 2014). Proposals in the form of simulation were presented in other countries, such as Germany (Droste et al., 2017b, 2018). In Brazil, EFT is included in the share of ICMS and they took on slightly different names: ICMS Ecológico, ICMS Verde and ICMS Socioambiental. $^{2}$ In the Portuguese case, this policy tool was introduced by the local finance law with the primary purpose of biodiversity conservation (Santos et al., 2012). There is empirical evidence of its effectiveness to enhance PAs (Droste et al., 2017c). Biodiversity conservation policy is also the primary purpose in Brazil, but other policies have been included, such as solid waste management and water conservation policies.

\section{Moving from EFT to a Sustainable development perspective}

Sixteen brazilian states adopt EFTs to stimulate the conservation of biodiversity. Nine of them include SWM criteria (de Paulo, 2019), while some others include water conservation criteria, as well as fire-control, indigenous land, health services, and education. Globally, EFT is intended to contribute to sustainable development at local governments.

Sustainable development seeks to secure the needs of future generations by limiting consumption and development in the present to an adequate level (World Commission on Environment and Development (WCED), 1987). The present generation must seek a reasonable level of environmental consumption, economic productivity, and social investment (Steer and Wade-Gery, 1993).

Sustainable development is a greater challenge to less-developed countries, as they have to deal simultaneously with poverty and environmental degradation. In addition, the 
most powerful political groups tend to steer the policy process of environmental policies (Steer and Wade-Gery, 1993). In this context, EFTs have the potential to incentivise and compensate local governments to formulate and implement policies related to biodiversity conservation and social development. With the implementation of such social and environmental policies, the less affluent municipalities may benefit from EFTs by receiving more money that improves their limited budgets.

In accordance with the theory of fiscal equivalence (Olson, 1969), EFTs internalise spillovers, which ensures that the marginal benefits from fiscal transfers compensate the marginal costs incurred in providing environmental and social policies by municipalities. For example, local PAs impose land-use restrictions to a municipality, but their benefits extend far beyond its boundaries. Another example is primary education offered by a municipality affecting its neighbours positively. In both cases, EFTs function as a policy tool to compensate local governments by transferring money. An element of incentive is also present in EFTs because local governments can be motivated to adopt environmental and social policies to receive more money.

In sum, EFTs are intergovernmental fiscal transfers to compensate and incentivise municipal governments in the implementation of environmental policies and, in some cases, of social policies also. Therefore, when such fiscal transfers include also social policies, we suggest SFTs rather than EFTs.

\section{Research design}

The analysis is focused on a case study of SFTs adopted in the State of Pernambuco, a scheme that is known as ICMS Socioambiental (law 11.899/2000). Two analyses were performed: the first is based on the evolution of SFT legislation over the period of 2002 to 2018; the second is based on the discussion of the current literature about the effectiveness of SFT. The information with regard to SFTs legislation was collected in the official gazette of the state of Pernambuco. The literature was searched using keywords "Ecological Fiscal Transfers", "Pernambuco", "ICMS Socioambiental", and "Brazil" in google academic.

\section{SFT: a case study of the State of Pernambuco}

\subsection{The prospect of the legislation}

According to article 154 of the Federal Constitution of Brazil (CF), municipalities are entitled to a share of $25 \%$ of the total amount raised by ICMS, a tax levied by the state governments. One-fourth of this amount can be used as a SFTs, while the remaining amount is transferred to municipalities using the fiscal value-added criterion (VAT).

States can design the transfers of ICMS based on environmental and social indicators. These fiscal transfers are non-earmarked, because municipalities are not limited to spend the money on any specific type of functional expenditure or project. The first inclusion of social and environmental criteria to transfer ICMS in the State of Pernambuco was in 2000 (law 11.899/2000) under the name ICMS Socioambiental. 
The SFT scheme in Pernambuco evolved over the years due to their redistributive effects. In fact, while one group of municipalities were able to meet the requirements to receive more money from ICMS, the other group was not prepared to meet such requirements and had no alternative other than the reduction of their budgets (Jatobá, 2005). This redistributive effect generated various conflicts that had been evident since the beginning of the policy implementation because the negatively affected municipalities lobbied the Association of Municipalities of the State of Pernambuco (Associação Municipalista do Estado de Pernambuco-AMUPE) to pressure both the legislative and the executive to modify or repeal the law (Jatobá, 2005).

In the beginning, Pernambuco designed SFTs to include six social, economic and ecological criteria:

i the relative share of each municipality $(15 \%)$

ii the conservation units, that is, the protected areas (1\%)

iii composting plant units or landfill (4\%)

iv health $(2 \%)$

$\mathrm{V}$ education $(2 \%)$

vi stimulus to increase tax revenue collected by municipalities (1\%).

The relative share of each municipality refers to the sum of differences between the index of each municipality in the previous year and the percentage of their relative share in the value-added in the state. This mechanism was created in the 1980 s to reduce the precariousness of the 'administrative statistics' on the fiscal value-added, whose measurement is based on the tax-collecting activity (de Paulo, 2013). Other criteria comprise environmental policies (protected areas, composting plants, and landfills), social policies (education, and health), and economic policies (the stimulus to increase tax revenue collected by municipalities). These criteria have changed over the years.

In 2018, fourteen criteria made up ICMS Socioambiental (State law 15.929/2016). Concerning environmental policies: protected areas, solid waste treatment and disposal, water sources, including rivers, and waste recycling installations. With regard to social policies: child mortality (inversely), teams in the family health program, the enrollment of children in early childhood public education-kindergartens, elementary public schools, development index of education, enrollment in primary public education, number of prisons and penitentiaries, and number of intentional lethal violent crimes (inversely). Concerning economic policies: the stimulus to increase tax revenue collected by municipalities and municipal gross domestic product (GDP) "per capita" (inversely).

To date, the state of Pernambuco has not implemented the qualitative assessment of the protected area. It comprises the set of measurements of protected areas to transfer the ICMS to municipalities (de Paulo, 2019).

\subsection{The compensation and incentive of ICMS socioambiental}

Federal, state, and municipal governments are entitled to create PAs in Brazil. SFTs mainly compensate local governments when the creation of PAs is up to the federal and state governments. It has the potential to reduce their opportunity cost, that is, the lost revenue for hosting PAs. 
Also, the SFTs are a compensating mechanism for local governments to cover waste management expenses. The ICMS Socioambiental includes two measurements for waste management: landfills and composting plants.

A municipality is compensated for providing other social policies too, such as crimefighting (reduction of the number of intentional lethal violent crimes, for example), health programs, and education policies. Other jurisdictions may appropriate the benefits of these policies without bearing the costs of them.

Based on the theory of collective action (Olson, 1965), the SFTs in the state of Pernambuco aim to reduce the free-riding among municipalities. Referring to the social, economic, and environmental policies of the 184 municipalities, SFTs incentivise individual actions that go unnoticed in large groups. Examples of policies incentivised by SFTs: biodiversity conservation, disposal of solid waste at the local sphere, the stimulus to increase tax revenue collected by municipalities, local health programs, the reduction of violent crimes, and primary education.

\subsection{Empirical studies}

da Silva Júnior and Sobral (2014) investigated whether SFTs in the state of Pernamuco incentivised municipal policies in education, health services, and local tax revenues. Findings point to a significant effect in health services, but also in the case of local tax revenues and education. da Silva Júnior et al. (2013) analysed the effectiveness of SFTs to enhance PA in Pernambuco and concluded they were inefficient. de Paulo (2013) investigated SFTs for PAs from 2008 to 2013 and found that the scheme loses performance over time, mainly among countryside municipalities. Paulo and Pedrosa (2009) study a single municipality and arrive to the same conclusion of the noneffectiveness of the policy tool to enhance policies at the local governments.

Overall, three recommendations seem to appear from the empirical studies: the first is the adoption of a quality index to evaluate the PAs (de Paulo and Pedrosa, 2009); considering that the SFTs are not earmarked, the second recommendation is the establishment of a municipal fund to support environmental policies (de Paulo and Pedrosa, 2009); the third is the monitorisation of the SFTs performance among municipalities (de Paulo and Pedrosa, 2015).

\section{Conclusion}

SFT emerge as a new alternative policy tool from the state government to local governments that can be used together with other policy tools, such as PES (Salzman, 2005). SFTs aim to incentivise local governments to expand their budgets through social, economic, and environmental policies, and compensate them for the marginal benefits of providing social and environmental policies in their territories. This new conceptualisation to EFTs was never proposed. This essay expands the potential of the EFTs to other policies at the local governments.

SFTs promise to encourage and compensate local governments as for fostering environmental conditions, particularly with regard to solid waste management and protected areas. With regard to the State of Pernambuco, SFT encompasses the treatment 
and disposal of solid waste, creation, and maintenance of protected areas, enhancement of municipal tax revenue, enhancement of local health programs, the reduction of violent crimes, and the improvement of primary education.

Based on empirical studies, a strong recommendation for the SFT schemes is to include qualitative criteria to evaluate the protected area and to involve all political actors that are relevant to the process of adopting SFTs. In addition, empirical studies raised the importance of creating a municipal fund for environmental policies and to monitor the performance of SFTs over time.

We recommend expanding empirical research about SFTs effectiveness in different environmental and social policies, such as water conservation policies, education, public security, indigenous land protection, and health programs.

\section{Acknowledgements}

This work was conducted during a scholarship financed by CAPES (Brazilian Federal Agency). Process number: 000954/2015-02. Also, this study was conducted at Research Center in Political Science (UID/CPO/0758/2019), University of Minho, and was supported by the Portuguese Foundation for Science and Technology and the Portuguese Ministry of Education and Science through national funds.

\section{References}

Borie, M., Mathevet, R., Letourneau, A., Ring, I., Thompson, J. and Marty, P. (2014) 'Exploring the contribution of fiscal transfers to protected area policy', Ecology and Society, Vol. 19, No. 1, Art., p.9, doi: 10.5751/ES-05716-190109.

da Silva Júnior, L.H. and Sobral, E.F.M. (2014) 'O ICMS socioambiental de pernambuco: uma avaliação dos componentes socioeconômicos da politca a partir do processo de markov', Planejamento E Políticas Públicas, Vol. 42, pp.189-217, Available at http://www.ipea. gov.br/ppp/index.php/PPP/article/view/291

da Silva Júnior, L.H., Pedrosa, B. and da Silva, M.F. (2013) 'Avaliação dos impactos do ICMS socioambiental na criação de unidades de conservação e unidades de tratamento de resíduos sólidos em pernambuco: uma análise a partir do método de diferenças-em-diferenças', Revista Economica Do Nordeste, Vol. 44, pp.557-572, Available at. https://ren.emnuvens.com.br/ ren/article/view/73

de Medeiros, N. (2013) Inovação Na Política Tributária: Uma Análise Da Difusão Do ICMS Ecológico No Brasil, Universidade de Brasília.

de Paulo, F.L.L. (2013) 'Imposto sobre circulação de mercadorias e serviços - ICMS socioambiental : avaliação da política do estado de pernambuco nos últimos cinco anos na perspectiva da gestão ambiental', Fórum Ambiental Da Alta Paulista, pp.47-65, doi: http://dx.doi.org/10.17271/19800827952013568

de Paulo, F.L.L. (2019) Studies on Ecological Fiscal Transfers in Brazil, Universidade do minho, Available at http://repositorium.sdum.uminho.pt/

de Paulo, F.L.L. and Pedrosa, I. (2009) 'O imposto sobre circulação de mercadorias e serviços ICMS socioambiental como incentivo à melhoria das políticas públicas ambientais em nível municipal: um exame de caso no município de camaragibe, pernambuco', Enfoque: Reflexão Contábil, Vol. 28, No. 2, pp.74-83, doi: 10.4025/enfoque.v28i2.8409. 
de Paulo, F.L.L. and Pedrosa, I. (2015) 'Planejamento estratégico ambiental de pernambuco e o município de araripina: a importância do acompanhamento de desempenho do ICMS socioambiental para a melhoria das políticas públicas ambientais em nível municipal', Cadernos De Administração, Vol. 23, No. 1, pp.1-8, doi: http://dx.doi.org/10.4025/ cadadm.v23i1.8394

Droste, N., Becker, C., Ring, I. and Santos, R. (2017a) 'Decentralization effects in ecological fiscal transfers: a Bayesian structural time series analysis for portugal', Environmental and Resource Economics, Springer Netherlands, Vol. 71, No. 4, pp.1-25, doi: 10.1007/s10640-017-0195-7.

Droste, N., Ring, I., Schroter-Schalaack, C. and Lenk, T. (2017b) 'Integrating ecological indicators into federal-state fiscal relations: a policy design study for Germany', Environmental Policy and Governance, Vol. 27, No. 5, pp.484-499, doi: 10.1002/eet.1774.

Droste, N., Lima, G.R., May, P.H. and Ring, I. (2017c) 'Municipal responses to ecological fiscal transfers in Brazil: a microeconometric panel data approach', Environmental Policy and Governance, Vol. 27, No. 4, pp.378-393, doi: 10.1002/eet.1760.

Droste, N., Ring, I., Santos, R. and Kettunen, M. (2018) 'Ecological fiscal transfers in Europe evidence-based design options for a transnational scheme', Ecological Economics, Elsevier, Vol. 147, February, pp.373-382, doi: 10.1016/j. ecolecon.2018.01.031.

Jatobá, J. (2005) 'El impuesto sobre circulación de mercaderías y servicios de transporte (ICMS) como instrumento económico para la gestión ambiental: el caso de brasil', in Acquatella, J. and Bárcena, A. (Eds.): Política Fiscal y Medio Ambiente: Bases Para Una Agenda Común, Santiago de Chile: Publicación de las Naciones Unidas, pp.127-166.

Loureiro, W. (2002) Contribuição do ICMS Ecológico á Conservação da Biodiversidade no Estado do paraná, $\mathrm{PhD}$ thesis, Universidade Federal do Paraná.

Moura, A.S. (2015) 'Imposto sobre circulação de mercadorias e serviços socioambiental: incentivos institucionais e legislação ambiental no brasil', Revista De Administração Pública, Vol. 49, No. 1, pp.165-187.

Oates, W. (2001) A Reconsideration of Environmental Federalism. Resources for the Future, Avaliable at: http://www.rff.org

Olson, M. (1965) The Logic of Collective Action: Public Goods and the Theory of Groups, Harvard University Press, Cambridge, Mass.

Olson, M. (1969) 'The principle of fiscal equivalence: the division of responsibility among different levels of government', American Economic Review, Vol. 59, p.479.

Pedrosa, I. (2013) 'O enfrentamento da crise ambiental: tecnologias organizacionais são de mais difícil implantação pelos governos municipais das regiões periféricas?', Seminário, XIII Modernização Tecnológica Periférica - FUNDAJ. Recife, pp.1-15, Available at http://www.nupesp.org/sites/default/files/smtp_trabalho_submetido_2013_20fev13.pdf

Ring, I. (2008) 'Integrating local ecological services into intergovernmental fiscal transfers: the case of the ecological ICMS in Brazil', Land Use Policy, Vol. 25, No. 4, pp.485-497, doi: 10.1016/j. landusepol.2007.11.001.

Ring, I. and Barton, N. (2015) 'Economic instruments in policy mixes for biodiversity conservation and ecosystem governance', in Martínez-Alier, J. and Muradian, R. (Eds.): Handbook of Ecological Economics, Edward Elgar, pp.413-449, doi: 10.4337/9781783471416.

Salzman, J. (2005) 'The promise and perils of payments for ecosystem services', International Journal of Innovation and Sustainable Development, Vol. 1, Nos. 1-2, pp.5-20, doi: 10.1504/ijisd.2005.008079.

Santos, R., Ring, I., Antunes, P. and Clemente, P. (2012) 'Fiscal transfers for biodiversity conservation: The Portuguese local finances law', Land Use Policy, Vol. 29, No. 2, pp.261-273, doi: 10.1016/j.landusepol.2011.06.001. 
Sauquet, A., Marchand S. and Féres, J.G. (2014) 'Protected areas, local governments, and strategic interactions: the case of the ICMS-ecológico in the Brazilian state of paraná', Ecological Economics. Elsevier, BV, Vol. 107, pp.249-258, doi: 10.1016/j.ecolecon.2014.09.008.

Steer, A. and Wade-Gery, W. (1993) 'Sustainable development: theory and practice for a sustainable future', Sustainable Development, Vol. 1, No. 3, pp.30-35, doi: 10.1002/ sd.3460010306.

World Commission on Environment, and Development (1987) Our Common Future: Report of the World Commission on Environment and Development, Oxford University Press.

\section{Notes}

${ }^{1}$ The Brazilian federation is considered in the literature as 'cooperative' because there are 'exclusive' and 'competing' competencies among federal, state, and municipal governments.

${ }^{2}$ Ecological ICMS, Green ICMS, and Social and Environmental ICMS respectively. 